\title{
PENGGUNAAN MODEL PEMBELAJARAN INQUIRI SEBAGAI UPAYA UNTUK MENINGKATKAN HASIL BELAJAR SISWA PADA MATERI TUMBUHAN HIJAU
}

\author{
Murniyati $^{1}$ dan Syifa Saputra ${ }^{2}$ \\ ${ }^{2}$ Program Studi Pendidikan Biologi Universitas Almuslim
}

\begin{abstract}
ABSTRAK
Proses pembelajaran yang terjadi belum terlibat secara aktif dikarnakan guru dalam mengajar cenderung bersifat informatif atau hanya transfer ilmu pengetahuan dari guru ke siswa sehingga siswa dalam belajar menjadi pasif dan kurang berminat dalam mengikuti pembelajaran IPA sehingga menyebabkan pemahaman akan konsep IPA siswa rendah. Tujuan penelitian untuk mengetahui peningkatan hasil belajar siswa, untuk mengetahui aktivitas guru dan siswa dan untuk mengetahui respon siswa dalam pembelajaran IPA pada materi Tumbuhan Hijau melalui model Inkuiri. Penelitian ini merupakan penelitian kualitatif dengan jenis Penelitian Tindakan Kelas. Subjek penelitian adalah siswa kelas V SD Negeri 8 Peusanagan Tahun ajaran 2017/2018 yang berjumlah 20 0rang. Data dikumpulkan dari tes, observasi, dan angket. Hasil belajar siswa pada siklus I sebesar $40 \%$ dan pada siklus II sebesar $80 \%$. Berdasarkan hasil penelitian yang telah dilakukan, diperoleh pada siklus I aktivitas guru sebesar 75\% dan aktivitas siswa 73,33\%. Sedangkan aktivitas guru pada siklus II sebesar 93,33\% dan aktivitas siswa sebesar 94,99\%. Respon siswa terhadap pembelajaran sudah cukup baik, dimana yang menyatakan senang sebesar $85,5 \%$ dan yang menyatakan tidak senang sebesar 4,5\%. Dengan demikian dapat disimpulkan bahwa penerapan model pembelajaran Inkuiri dapat meningkatkan hasil belajar siswa pada materi tumbuhan hijau, aktivitas guru dan siswa sudah berlangsung dengan baik serta mendapatkan respon yang baik dari siswa.
\end{abstract}

Kata Kunci : Hasil Belajar, Tumbuhan Hijau dan Model Inkuiri

\section{PENDAHULUAN}

Capaian tujuan pendidikan formal dan sesuai adalah sesuatu yang diharapkan, terutama dalam meningkatkan mutu proses pembelajaran, jumlah serta kualitas tenaga pengajar juga harus ditingkatkan melalui pengembangan dan penerapan model efektif dan efesien. Pendidikan masih memegang peranan yang sangat penting, dalam meningkatkan sumber daya manusia menuju kearah yang lebih baik. Faktor penyebab tidak tercapainya hasil yang maksimal berdampak pada kurangnya kemampuan guru dalam melihat kondisi persta didikk dan menciptakan suasana pembelajaran yang menarik, sehingga diperlukan keahlian untuk menerapkan strategi pembelajaran yang sesuai dengan mata pelajaran yang diampu.

Salah satu model yang dikembangkan untuk meningkatkan hasil belajar siswa adalah Model pembelajaran inkuiri. Dalam hal ini Trianto (2009) mengatakan Model pembelajaran inkuiri suatu rangkaian kegiatan pembalajaran yang lebih menekankan pada proses berfikir secara kritis dan analitis untuk mencari dan menemukan sendiri jawaban dari suatu masalah, yang dilakukan melalui diskusi dan tanya jawab antara guru dan siswa. Penerapan model inkuiri 
berupaya menanamkan pola dasar dalam berpikir ilmiah terhadap diri siswa sebagai subjek belajar, sehingga siswa lebih banyak belajar, mengembangkan kreativitas dalam memecahkan masalah secara mandiri. Disamping itu, Saputra (2016) memberikan pandangan bahwa kreatifitas, inovatif, efektif dan menyenangkan adalah sebuah tuntutan yang harus dipenuhi oleh pendidik agar siswa dapat lebih aktif dalam mencapai tujuan kompetensi yang diharapkan ayng akhirnya akan mempengaruhi keberhasilan dalam proses pembelajaran. Lebih lanjut Elisa, dkk (2018) hasil belajar adalah penilaian akhir dari suatu proses yang di lakukan berulang-ulang yang hasil belajar turut serta membentuk individu yang selalu ingin mendapatkan hasil yang lebih baik sehingga akan merubah pola berpikir serta prilaku kerja yang lebih baik.

Sudjana (2010) menyatakan bahwa belajar merupakan suatu proses yang ditandai dengan adanya perubahan perilaku pada seseorang. Perubahan hasil proses belajar dapat ditunjukkan dengan berbagai bentuk peningkatan pengetahuan, pemahaman, sikap dan etika, sill, kebiasaan serta perubahan aspek-aspek lain yang terdapat pada individu-individu yang belajar. Perubahan-perubahan tersebut akan nyata dalam seluruh aspek tingkah laku. Mulyasa (2009) hasil belajar merupakan hasil belajar peserta didik secara keseluruhan yang menjadi indikator kompetensi dasar dan derajat perubahan tingkah laku yang bersangkutan. Dalam hal ini, guru dituntut memiliki keterampilan-keterampilan dalam penyampaian materi pembelajaran. Sehingga materi yang disampaikan dapat mudah dipahami oleh setiap peserta didik. Dalam proses belajar mengajar belajar harus berlandaskan pada aktivitas-aktivitas pembelajaran yang bersifat alamiah. Sedangkan Dimiyati dan Mudjiono (2009) dan Suprijono (2009) dalam hal ini juga berpendapat hasil belajar adalah hal yang dapat di pandang dari sisi siswa dan guru. Dari sisi siswa hasil belajar adalah tingkatan perkembangan mental yang mengarah pada ranah kognitif, afektif dan psikomotorik. kognitif adalah knowledge (Pengetahuan, ingatan), comprehension (Pemahaman, menjelaskan, meringkas, contoh), application (menerapkan), analysis (Menguraikan, menentukan hubungan), Synthesis (Mengorganisasikan, merencanakan, membentuk bangunan baru), dan evaluation (Menilai). Domain Afektif adalah receiving (sikap menerima), responding (Memberikan respon), valuing (Nilai), organization (Organisasi), characterization (Karakterisasi). Sedangkan Psikomotorik juga mencakup keterampilan produktif, teknik, fisik, sosial, manajerial, dan intelektual.

Model pembelajaran inkuiri adalah suatu rangkaian pelaksanaan kegiatan yang mengarah kepada proses berfikir kritis dan analisis untuk mencari serta menemukan sendiri jawaban dari masalah yang dipertanyakan (Trianto, 2009). Tujuan utama pembelajaran melalui strategi inkuiri adalah menolong siswa untuk dapat mengembangkan disiplin intelektual dan keterampilan berfikir dengan memberikan pertanyaan-pertanyaan dan mendapatkan jawaban atas dasar rasa ingin tahu siswa.

Hasil observasi diperoleh informasi bahwa sebagian besar guru mengajar cenderung bersifat informatif yang berarti cenderung terhadap mentransfer ilmu pengetahuan dari guru ke siswa sehingga siswa tidak terlibat secara aktif yang berakibat pada siswa dalam belajar menjadi 
pasif yang menyebabkan pemahaman konsep Sains (IPA) dan akan berdampak pada rendahnya hasil belajar. Hal ini dapat dibuktikan dengan Nilai yang diperoleh tidak memenuhi nilai KKM yaitu $\geq 73$ dan tidak memenuhi nilai KKM pada materi Tumbuhan Hijau sebesar $35 \%$. Selain itu, siswa juga belum sepenuhnya menyukai pembelajaran Sain (IPA) yang disebabkan oleh kurangnya minat belajar maupun kreativitas yang dimiliki oleh siswa.

Berdasarkan latar belakang masalah di atas bahwa guru IPA di SD Negeri 8 Peusangan belum menggunakan pendekatan pembelajaran yang dapat memotivasi keaktifan belajar siswa sehingga siswa terlibat pasif dan kurang berminat dalam mengikuti pelajaran IPA, sehingga hasil belajar yang diperoleh siswa pada mata pelajaran IPA rendah, untuk itu diupayakan suatu pendekatan pembelajaran yang dapat meningkatkan hasil belajar siswa dalam mengikuti pelajaran IPA. Dalam proses pembelajaran untuk meningkatkan hasil belajar dan keaktifan belajar siswa maka dilakukan suatu penelitian dengan judul "Penggunaan Model Pembelajaran Inquiri Sebagai Upaya Untuk Meningkatkan Hasil Belajar Siswa Pada Materi Tumbuhan Hijau".

\section{METHODOLOGI PENELITIAN}

Pendekatan dalam penelitian yang digunakan adalah kualitatif, karena peneliti ingin memperoleh data yang mendalam dan secara alamiah tentang langkah-langkah yang dilakukan siswa dalam menjawab soal-soal. Menurut Moleong (2010:4-7) penelitian kualitatif akan menghasilkan data deskriptif berupa kata-kata tertulis atau lisan dan perilaku seseorang yang diamati.

Jenis penelitian yang digunakan adalah penelitian tindakan kelas dimana dalam penelitian ini terdapat tindakan yang baik untuk meningkatkan suatu pembelajaran dikelas. Dalam penelitian tidakan kelas peneliti bertindak sebagai instrument utama, karena peneliti merencanakan, merancang, melaksanakan, mengumpulkan data, menarik kesimpulan dan membuat laporan penelitian.

Penelitian Tindakan Kelas (PTK) adalah penelitian yang dilakukan oleh guru dikelasnya sendiri dengan cara merencanakan, melaksanakan dan merefleksi tindakan secara kolaboratif dan parsitipatif dengan tujuan memperbaiki kinerjanya sebagai guru, sehingga hasil belajar siswa dapat meningkat. Dalam penelitian tindakan kelas peneliti bertindak sebagai instrument utama, karena peneliti yang merencanakan, merancang, melaksanakan, mengumpulkan data, menganalisis data,menarik kesimpulan dan membuat laporan penelitian. Sumber data yang didapatkan adalah dari hasil belajar siswa, aktivitas guru dan siswa serta respon siswa yang diperoleh melalui angket sehingga bertujuan untuk mengetahui respon siswa terhadap pelaksanaan kegiatan pembelajaran dengan menggunakan model Inkuiri.

Sedangkan untuk teknik pengumpulan data yang dikumpulkan adalah dengan melakukan tes, observasi dan angket respon siswa. dalam menganalisis data yang diperoleh meliputi : 
1. Hasil belajar

Untuk menghitung daya serap masing-msaing siklus. Dengan rumus sebagai berikut:

$$
\text { Daya serap }=\frac{\text { Banyaknya siswa yang tuntas }}{\text { Jumlah siswa }} \times 100 \%
$$

Dengan kriteria ketuntasan adalah masing-masing siswa mampu menyelesaikan 35\% dari tes yang diberikan.Sedangkan ketuntasan klasikal adalah jika daya serapnya mencapai $73 \%$.

2. Aktivitas Guru dan Siswa

Diperoleh melalui hasil pengamatan dengan menggunakan format pengamatan. Data yang diperoleh melalui format pengamatan dianalisis dengan menggunakan skor masingmasing komponen penilaian, selanjutnya diolah dengan rumus :

$$
\text { Skor Total }=\frac{\text { Skor yang diperoleh }}{\text { Skor maksimum }} \times 100 \%
$$

Sedangkan untuk menentukn skor presentase rata-rata setiap tindakan untuk aktivitas guru dan siswa, maka digunakan rumus yaitu:

Presentase rata-rata $(N R)=\frac{s p 1+s p 2}{2}$

Keterangan:

$\mathrm{SP} 1$ = pengamat 1

SP 2 = pengamat 2

Dimana kriteria taraf keberhasilan tindakan aktifitas guru dan siswa, yaitu:

$$
\begin{array}{ll}
90 \%<\mathrm{SP}<100 \% & =\text { Sangat Baik } \\
80 \%<\mathrm{SP}<90 \% & =\text { Baik } \\
70 \%<\mathrm{SP}<80 \% & =\text { Cukup } \\
& \\
60 \%<\mathrm{SP}<70 \% & =\text { Kurang } \\
0 \%<\mathrm{SP}<60 \% & =\text { Sangat Kurang }
\end{array}
$$

3. Respon Siswa

Untuk mengetahui respon siswa dengan mempresentasikan jawaban dari angket yang diberikan kepada siswa dengan statistik deskriptif sebagai berikut:

$$
\mathrm{P}=\frac{f}{N} \mathrm{X} 100 \%(\text { Sudjono, 2007:43) }
$$

Dimana:

$$
\begin{array}{ll}
\mathrm{P} & =\text { persentase yang dicari } \\
\mathrm{F} & =\text { Frekuensi jawaban siswa } \\
\mathrm{N} & =\text { Jumlah siswa }
\end{array}
$$




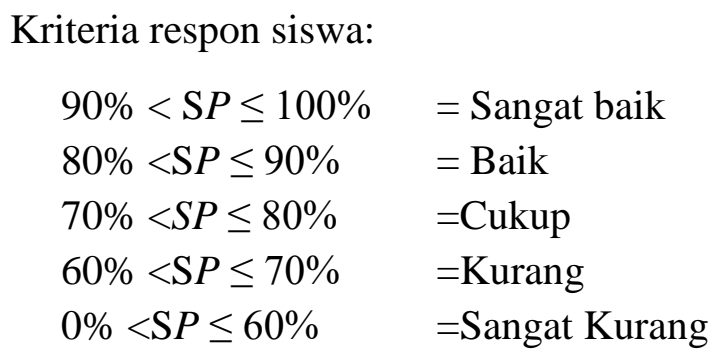

\section{HASIL DAN PEMBAHASAN}

\section{Hasil}

Pelaksanaan siklus I terdiri dari dua kali pertemuan. Pertemuan I dilaksanakan dengan menyajikan Proses tumbuhan hijau membuat makanan. Sedangkan untuk pelaksanaan pembelajaran pertemuan II dilaksanakan dengan menyajikan proses tumbuhan hijau menyimpan cadangan makanan.

Pelaksanaan siklus II terdiri dari dua kali pertemuan. Pertemuan I dengan materi yang disajikan adalah pentingnya tumbuhan hijau bagi manusia dan hewan sebagai sumber energi. Sedangkan untuk pertemuan II materi yang disajikan adalah keadaan dunia tanpa tumbuhan hijau, serta melakukan ujian siklus II dan pembagian angket respon siswa terhadap pelaksanaan pembelajaran.

\section{Siklus I Tindakan I}

a. Perencanaan

Pada tahap perencanaan peneliti melakukan beberapa persiapan, diantaranya menyiapkan Rencana Pelaksanaan Pembelajaran (RPP) dengan materi proses tumbuhan hijau membuat makanan sendiri, menyiapkan LKS yang berkaitan dengan materi yang akan dipelajari, menyiapkan alat dan bahan belajar, menyiapkan lembar observasi aktivitas guru dan siswa untuk mengamati aktivitas guru dan siswa selama pelaksanaan pembelajaran.

b. Pelaksanaan

Tindakan pembelajaran dilaksanakan sesuai dengan langkah-langkah yang tertera pada Rencana Pelaksanaan Pembelajaran (RPP) dan sesuai dengan model pembelajaran Inkuiri.Tindakan I siklus I di ikuti oleh 20 orang siswa.

Fase I : Penyajian Masalah

Guru memotivasi siswa dengan memberikan pertanyaan bagaimanakah cara tumbuhan hijau membuat makanan? Selanjutnya guru menginformasikan pentingnya materi tumbuhan hijau dan model pembelajaran yang akan digunakan yaitu model Inkuiri. Guru menjelaskan pokok-pokok kegiatan yang harus dilakukan oleh siswa untuk mencapai tujuan belajar dan memberikan permasalahan untuk membuktikan tentang fotosintesis dalam kehidupan sehari-hari. 
Fase II : Membuat Hipotesis

Fase ini guru meminta siswa mencari jawaban sementara dari teks yang ada pada LKS 01 yang diberikan. Selanjutnya guru meminta siswa mengisi jawaban pada LKS 01. Guru membimbing siswa yang mengalami kesulitan dalam mengisi LKS.

Fase III : Merancang Percobaan

Fase ini Guru mendemontrasikan langkah percobaan fotosintesis, dan membimbing siswa dalam merancang percobaan di depan kelas. Guru membimbing siswa melakukan pengamatan pada percobaan yang telah didemontrasikan.

Fase IV : Melakukan percobaan untuk memperoleh informasi

Fase ini guru membimbing siswa dalam kelompok belajar, guru membentuk kelompok terdiri dari 4-5 siswa, guru membimbing siswa untuk melakukan penyelidikan sesuai dengan demontrasi yang telah diberikan.

Fase V : Mengumpulkan data dan menganalisis data

Fase ini guru membimbing siswa dalam kelompok untuk mencatat dan mendiskusikan hasil pengamatan, guru memberikan bimbingan kepada siswa untuk menganalisis hasil pengamatan, guru meminta siswa untuk membuat laporan hasil pengamatan, guru menyuruh siswa untuk mempresentasikan laporan hasil pengamatan kelompok di depan kelas dan kelompok lain menanggapinya.

Fase VI : Membuat Kesimpulan

Fase ini Guru merefleksikan hasil diskusi dan presentasi kelompok, guru memberikan informasi lebih lanjut tentang tumbuhan hijau dan fotosintesis, guru meminta siswa untuk membuat rangkuman pembelajaran.

c. Pengamatan

Pengamatan dilakukan bersamaan dengan pelaksanaan kegiatan pembelajaran. Dalam pelaksanaan pembelajaran peneliti dibantu oleh dua orang pengamat yang bertindak sebagai observatory. Adapun indikator-indikator yang diamati meliputi aktivitas guru (peneliti) dalam pelaksanaan tindakan dan aktivitas siswa dalam proses belajar mengajar.

d. Analisis dan Refleksi

\section{1) Analisis aktivitas guru siklus I Pertemuan I}

Aktivitas guru dalam melaksanakan pembelajaran diamati dengan menggunakan lembar observasi kegiatan guru dalam pengelolaan model pembelajaran Inkuiri. Adapun hasil pengamatan aktivitas guru pada siklus I pertemuan I disajikan pada tabel 1 di bawah ini: 
Tabel 1 Analisis Aktivitas Guru Siklus 1 Tindakan 1

\begin{tabular}{|c|c|c|c|c|c|c|}
\hline \multirow[t]{2}{*}{ No } & \multirow[t]{2}{*}{ Fase } & \multicolumn{2}{|c|}{$\begin{array}{c}\text { Skor } \\
\text { Aktivitas } \\
\text { Guru }\end{array}$} & \multirow[t]{2}{*}{$\begin{array}{l}\text { Skor } \\
\text { Rata- } \\
\text { Rata }\end{array}$} & \multirow[t]{2}{*}{ Persentase } & \multirow[t]{2}{*}{ Kriteria } \\
\hline & & PI & PII & & & \\
\hline 1 & 2 & 3 & 4 & 5 & 6 & 7 \\
\hline 1 & Menyajikan Masalah & 4 & 4 & 8 & $80 \%$ & $\mathrm{~B}$ \\
\hline 2 & Membuat Hipotesis & 4 & 4 & 8 & $80 \%$ & B \\
\hline 3 & Merancang percobaan & 4 & 3 & 7 & $70 \%$ & $\mathrm{C}$ \\
\hline 4 & $\begin{array}{l}\text { Melakukan } \\
\text { Percobaan untuk } \\
\text { memperoleh } \\
\text { Informasi }\end{array}$ & 3 & 4 & 7 & $70 \%$ & $\mathrm{C}$ \\
\hline 5 & $\begin{array}{l}\text { Mengumpulkan data } \\
\text { dan menganalisis data }\end{array}$ & 3 & 4 & 7 & $70 \%$ & $\mathrm{C}$ \\
\hline 6 & $\begin{array}{l}\text { Membuat } \\
\text { Kesimpulan }\end{array}$ & 4 & 3 & 7 & $70 \%$ & $\mathrm{C}$ \\
\hline & Jumlah & 22 & 22 & 44 & $73,33 \%$ & $\mathbf{C}$ \\
\hline
\end{tabular}

Berdasarkan tabel 1 terlihat bahwa aktivitas yang dilakukan guru pada fase menyajikan masalah diperoleh skor 4 oleh pengamat 1 dan skor 4 oleh pengamat II. Sehingga perolehan skor rata-rata adalah 8 , sedangkan untuk persentase yang diperoleh pada fase menyajikan masalah adalah $80 \%$ dan termasuk dalam kriteria baik.Sedangkan pada fase Membuat Hipotesis diperoleh skor 4 oleh pengamat 1 dan skor 3 oleh pengamat II. Skor rata-rata 8.vPersentase yang diperoleh pada fase Membuat Hipotesis adalah $80 \%$ dan termasuk dalam kriteria baik.

Fase Merancang Percobaan diperoleh skor 4 oleh pengamat 1 dan skor 3 oleh pengamat II.vSkor rata-rata adalah 7.vPersentase yang diperoleh pada fase Merancang Percobaan adalah $80 \%$ dan termasuk dalam kriteria baik.vFase melakukan percobaan untuk memperoleh informasi, diperoleh skor 3 pengamat 1 dan skor 4 oleh pengamat II.Skor rata-rata adalah 7. Persentase yang diperoleh pada fase melakukan percobaan untuk memperoleh informasi adalah $70 \%$ dan termasuk dalam kriteria cukup, untuk memperoleh informasi diperoleh skor 3 oleh pengamat 1 dan skor 4 oleh pengamat II. Skor rata-rata adalah 7 Persentase yang diperoleh pada fase Melakukan Percobaan untuk memperoleh informasi adalah $70 \%$ dan termasuk dalam kriteria cukup.vFase membuat kesimpulan diperoleh skor 4 oleh pengamat 1 dan skor 3 oleh pengamat II.

Skor rata-rata adalah 7. Persentase yang diperoleh pada fase membuat kesimpulan adalah $70 \%$ dan termasuk dalam kriteria baik. Keseluruhan skor rata-rata dari aktivitas guru adalah 44 dan persentase $73,33 \%$. Dengan demikian, termasuk dalam kriteria cukup. 


\section{2) Analisis Aktivitas Siswa Siklus 1 Tindakan 1}

Aktivitas siswa dalam melaksanakan pembelajaran diamati dengan menggunakan lembar observasi kegiatan siswa dalam mengikuti model pembelajaran Inkuiri. Adapun hasil pengamat aktivitas siswa pada siklus I tindakan I terdapat pada tabel 2 di bawah ini:

Tabel 2 Analisis Aktivitas Siswa Siklus I dan Tindakan I

\begin{tabular}{|c|c|c|c|c|c|c|}
\hline \multirow[t]{2}{*}{ No } & \multirow[t]{2}{*}{ Fase } & \multicolumn{2}{|c|}{$\begin{array}{c}\text { Skor } \\
\text { Aktivitas } \\
\text { Siswa }\end{array}$} & \multirow[t]{2}{*}{$\begin{array}{l}\text { Skor } \\
\text { Rata- } \\
\text { Rata }\end{array}$} & \multirow[t]{2}{*}{ Persentase } & \multirow[t]{2}{*}{ Kriteria } \\
\hline & & PI & PII & & & \\
\hline 1 & 2 & 3 & 4 & 5 & 6 & 7 \\
\hline 1 & Menyajikan Masalah & 3 & 4 & 7 & $70 \%$ & $\mathrm{C}$ \\
\hline 2 & Membuat Hipotesis & 3 & 4 & 7 & $70 \%$ & $\mathrm{C}$ \\
\hline 3 & Merancang percobaan & 4 & 3 & 7 & $70 \%$ & $\mathrm{C}$ \\
\hline 4 & $\begin{array}{l}\text { Melakukan Percobaan } \\
\text { untuk memperoleh } \\
\text { Informasi }\end{array}$ & 4 & 4 & 8 & $80 \%$ & B \\
\hline 5 & $\begin{array}{l}\text { Mengumpulkan data } \\
\text { dan menganalisis data }\end{array}$ & 4 & 4 & 8 & $80 \%$ & B \\
\hline 6 & Membuat Kesimpulan & 4 & 3 & 7 & $70 \%$ & $\mathrm{C}$ \\
\hline & Jumlah & 22 & 22 & 44 & $73,33 \%$ & $\mathbf{C}$ \\
\hline
\end{tabular}

Berdasarkan tabel 2 diatas, terlihat bahwa aktivitas yang dilakukan siswa pada fase Menyajikan Masalah diperoleh skor 3 oleh pengamat 1 dan skor 4 oleh pengamat II. Skor rata-rata 7. Persentase yang diperoleh pada fase Menyajikan Masalah adalah $70 \%$ dan termasuk dalam kriteria cukup.Sedangkan pada fase Membuat Hipotesis diperoleh skor 3 oleh pengamat 1 dan skor 4 oleh pengamat II. Skor rata-rata adalah 7. Persentase yang diperoleh pada fase Membuat Hipotesis adalah $70 \%$ dan termasuk dalam kriteria cukup. Fase Merancang Percobaan diperoleh skor 4 oleh pengamat 1 dan skor 3 oleh pengamat II. Skor rata-rata adalah 7.

Persentase yang diperoleh pada fase Merancang Percobaan adalah 70\% dan termasuk dalam kriteria cukup. Fase melakukan Percobaan untuk memperoleh informasi 4, diperoleh skor 4 oleh pengamat 1 dan skor 4 oleh pengamat II. Skor rata-rata adalah 8. Persentase yang diperoleh pada fase melakukan Percobaan untuk memperoleh informasi adalah $80 \%$ dan termasuk dalam kriteria baik. Fase Mengumpulkan data dan menganalisis data diperoleh skor 4 oleh pengamat I dan skor 4 oleh pengamat II.

Skor rata-rata adalah 8 . Persentase yang diperoleh pada fase mengumpulkan data dan menganalisis data adalah $80 \%$ dan termasuk dalam kriteria baik.Fase Membuat Kesimpulan diperoleh skor 4 oleh pengamat I dan skor 3 oleh pengamat II. Skor ratarata adalah 7. Persentase yang diperoleh pada fase membuat kesimpulan adalah $70 \%$ 
dan termasuk dalam kriteria cukup. Keseluruhan skor rata-rata dari aktivitasnsiswa adalah 44 dan persentase 73,33\%. Dengan demikian, termasuk dalam kriteria cukup.

3) Refleksi Siklus I Tindakan I

Hasil pengamatan dan analisis data yang diperoleh peneliti dan dua orang pengamat selama proses pembelajaran tindakan I siklus I, dan sudah terlihat pengaruh dari penggunaan model pembelajaran Inkuiri, selama kegiatan pembelajaran berlangsung. Pengaruh dari tindakan yang diberikan guru dapat terlihat dari keberhasilan dan kelemahan, baik dari segi guru dan siswa antara lain:

a. Kelebihan guru dan siswa

b. Aktivitas yang dilakukan guru sudah terlaksana dengan baik, hal ini terlihat dari keberhasilan guru dalam menerapkan kegiatan pembelajaran, seperti pada fase 1, fase 2 dan fase 6 .

c. Kelemahan guru dan siswa

- Aktivitas guru belum dilakukan secara maksimal, seperti kurang mampunya guru dalam memberikan motivasi sehingga perhatian siswa masih kurang fokus terhadap pembelajaran, dalam mendemontrasikan pengetahui guru juga belum melaksanakan dengan baik, sehingga siswa kurang dapat memahami materi yang diajarkan. Hal ini juga terlihat dari aktivitas guru pada tindakan I dengan persentase sebesar 73,33\% dan termasuk dalam kriteria cukup.

- Aktivitas yang dilakukan oleh siswa juga masih rendah dengan persentase sebesar 73,33\% dan termasuk dalam kategori cukup. Dimana perhatian siswa masih rendah ketika guru menyampaikan materi pelajaran, pada tahap pembentukan kelompok siswa juga terlihat kurang menerima keberadaan kelompok, ketika siswa mengerjakan LKS juga terlihat lebih menonjol siswa yang pintar, sedangkan siswa yang lainnya hanya memperhatikan saja. Siswa juga tidak memberikan komentar saat guru memintanya untuk menanggapi hasil presentasi kelas.

Berdasarkan kelemahan-kelemahan di atas, maka perlu diadakan tindakan II untuk memperbaikinya.

\section{Siklus I Tindakan II}

\section{a. Perencanaan}

Tahap ini peneliti melakukan beberapa persiapan, diantaranya adalah menyiapkan rencana pelaksanaan pembelajaran (RPP) dengan materi Tumbuhan Hijau menyimpan cadangan makanan, menyiapkan LKS yang berkaitan dengan materi yang akan dipelajari, menyiapkan alat dan bahan belajar seperti jenis-jenis Tumbuhan Hijau yang menyimpan cadangan makanan, menyiapkan lembar observasi aktivitas guru dan siswa untuk mengamati aktivitas guru dan siswa selama pelaksanaan pembelajaran, serta menyiapkan tes hasil belajar siswa akhir siklus I. 


\section{b. Pelaksanaan}

Pelaksanaan tindakan II dilaksanakan sesuai dengan langkah-langkah yang tertera pada Rencana Pelaksanaan Pembelajaran (RPP) sesuai dengan model pembelajaran Inkuiri Tindakan II siklus I diikuti oleh 20 orang siswa.

Fase I : Menyajikan Masalah

Memotivasikan siswa dengan memberikan pertanyaan dimanakah tumbuhan hijau menyimpan cadangan makanan?, menginformasikan pentingnya materi tumbuhan hijau dan model pembelajaran yang akan digunakan yaitu model Inkuiri. Guru menjelaskan pokok-pokok kegiatan yang harus dilakukan oleh siswa untuk mencapai tujuan belajar. Guru memberikan permasalahan untuk membuktikan tentang tempat tumbuhan hijau dalam menyimpan cadangan makanan.

Fase II : Membuat Hipotesis

Pada fase ini Guru meminta siswa mencari jawaban sementara dari teks yang ada pada LKS 02 yang diberikan guru sesuai materi selanjutnya guru meminta siswa untuk mengisi jawaban pada LKS 02, guru membimbing siswa yang mengalami kesulitan dalam mengisi LKS.

Fase III : Merancang Percobaan

Pada fase ini Guru mendemontrasikan langkah percobaan tempat tumbuhan hijau menyimpan cadangan makanan selanjutnya guru membimbing siswa dalam merancang percobaan di depan kelas dan guru membimbing siswa melakukan pengamatan pada percobaan yang telah didemontrasikan.

Fase IV : Melakukan Percobaan untuk memperoleh informasi

Guru membimbing siswa dalam kelompok belajar selanjutnya guru membentuk kelompok terdiri dari 4-5 orang siswa dan guru membimbing siswa untuk melakukan penyelidikan sesuai dengan demontrasikan yang telah diberikan.

Fase V : Mengumpulkan data dan menganalisis data

Pada fase ini membimbing siswa dalam kelompok untuk mencatat dan mendiskusikan hasil pengamatan dan guru memberikan bimbingan kepada siswa untuk menganalisis hasil pengamatan. Selanjutnya guru meminta siswa untuk mengisi laporan hasil pengamatan, guru menyuruh siswa untuk mempresentasikan laporan hasil pengamatan perkelompok didepan kelas dan kelompok lain menanggapinya.

Fase VI : Membuat Kesimpulan

Pada fase ini guru merefleksi hasil diskusi dan presentasi kelompok dan guru memberikan informasi lebih lanjut tempat tumbuhan hijau menyimpan cadangan makanan selanjutnya guru meminta siswa untuk membuat rangkuman pembelajaran.

\section{c. Pengamatan}


Pengamatan dilakukan bersamaan dengan pelaksanaan kegiatan pembelajaran.Dalam pelaksanaan pembelajaran peneliti dibantu oleh dua orang pengamat yang bertindak sebagai observator. Adapun indikator-indikator yang diamati meliputi aktivitas guru (peneliti) dalam pelaksanaan tindakan dan aktivitas siswa dalam proses belajar mengajar.

\section{d. Analisis dan Refleksi}

\section{1) Analisis Aktivitas Guru Siklus I Tindakan II}

Aktivitas guru dalam melaksanakan pembelajaran diamati dengan menggunakan lembar observasi kegiatan guru dalam pengelolaan model pembelajaran Inkuiri. Adapun hasil pengamatan aktivitas guru pada siklus I tindakan II terdapat pada tabel 3 berikut ini :

Tabel 3 Analisis Aktivitas Guru Siklus I Tindakan II

\begin{tabular}{|c|c|c|c|c|c|c|}
\hline \multirow[t]{2}{*}{ No } & \multirow[t]{2}{*}{ Fase } & \multicolumn{2}{|c|}{$\begin{array}{c}\text { Skor } \\
\text { Aktivitas } \\
\text { Guru }\end{array}$} & \multirow[t]{2}{*}{$\begin{array}{l}\text { Skor } \\
\text { Rata- } \\
\text { Rata }\end{array}$} & \multirow[t]{2}{*}{ Persentase } & \multirow[t]{2}{*}{ Kriteria } \\
\hline & & PI & PII & & & \\
\hline 1 & 2 & 3 & 4 & 5 & 6 & 7 \\
\hline 1 & Menyajikan Masalah & 4 & 4 & 8 & $80 \%$ & $\mathrm{~B}$ \\
\hline 2 & Membuat Hipotesis & 3 & 4 & 7 & $70 \%$ & $\mathrm{C}$ \\
\hline 3 & Merancang percobaan & 4 & 4 & 8 & $80 \%$ & B \\
\hline 4 & $\begin{array}{l}\text { Melakukan Percobaan } \\
\text { untuk memperoleh } \\
\text { Informasi }\end{array}$ & 3 & 4 & 7 & $70 \%$ & $\mathrm{C}$ \\
\hline 5 & $\begin{array}{l}\text { Mengumpulkan data } \\
\text { dan menganalisis data }\end{array}$ & 4 & 4 & 8 & $80 \%$ & $\mathrm{~B}$ \\
\hline 6 & Membuat Kesimpulan & 3 & 4 & 7 & $70 \%$ & $\mathrm{C}$ \\
\hline & Jumlah & 21 & 24 & 45 & $75 \%$ & $\mathbf{C}$ \\
\hline
\end{tabular}

Berdasarkan tabel 3 di atas, terlihat bahwa aktivitas yang dilakukan guru pada fase Menyajikan Masalah diperoleh skor 4 oleh pengamat 1 dan skor 4 oleh pengamat II. Skor rata-rata adalah 8. Persentase yang diperoleh pada fase Menyajikan Masalah adalah $80 \%$ dan termasuk dalam kriteria baik.Sedangkan pada fase Membuat Hipotesis diperoleh skor 3 oleh pengamat 1 dan skor 4 oleh pengamat II.

Skor rata-rata adalah 7. Persentase yang diperoleh pada fase Membuat Hipotesis adalah $70 \%$ dan termasuk dalam kriteria cukup. Fase Merancang Percobaan, diperoleh skor 4 oleh pengamat 1 dan skor 4 oleh pengamat II. Skor rata-rata adalah 8 . Persentase yang diperoleh pada fase Merancang Percobaan adalah 80\% dan termasuk dalam kriteria baik. Melakukan Percobaan untuk memperoleh informasi 4, diperoleh skor 3 oleh pengamat 1 dan skor 4 oleh pengamat II. Skor rata-rata adalah 7.Persentase yang diperoleh pada fase adalah $70 \%$ dan termasuk dalam kriteria cukup. Mengumpulkan data dan menganalisis data diperoleh skor 4 oleh pengamat 1 dan skor 
4 oleh pengamat II. Skor rata-rata adalah 8. Peresentase yang diperoleh pada fase Mengumpulkan data dan menganalisis data adalah $80 \%$ dan termasuk dalam kriteria baik. Fase membuat kesimpulan diperoleh skor 3 oleh pengamat 1 dan skor 4 oleh pengamat II. Skor rata-rata adalah 7. Persentase yang diperoleh pada fase Membuat Kesimpulan adalah $80 \%$ dan termasuk dalam kriteria baik.Keseluruhan skor rata-rata dari aktivitas guru adalah 45 dan persentase $75 \%$. Dengan demikian, termasuk dalam kriteria cukup.

\section{2) Analisis Aktivitas Siswa Siklus I Tindakan II}

Aktivitas siswa dalam melaksanakan pembelajaran diamati dengan menggunakan lembar obsevasi kegiatan siswa dalam mengikuti model pembelajaran Inkuiri. Adapun hasil pengamatan aktivitas siswa pada siklus I tindakan II terdapat pada tabel 4 di bawah ini :

Tabel 4 Analisis Aktivitas Siswa Siklus I Tindakan II

\begin{tabular}{|c|c|c|c|c|c|c|}
\hline \multirow[t]{2}{*}{ No } & \multirow[t]{2}{*}{ Fase } & \multicolumn{2}{|c|}{$\begin{array}{c}\text { Skor } \\
\text { Aktivitas } \\
\text { Siswa }\end{array}$} & \multirow{2}{*}{$\begin{array}{l}\text { Skor } \\
\text { Rata- } \\
\text { Rata }\end{array}$} & \multirow[t]{2}{*}{ Persentase } & \multirow[t]{2}{*}{ Kriteria } \\
\hline & & $\overline{\mathbf{P I}}$ & PII & & & \\
\hline 1 & 2 & 3 & 4 & 5 & 6 & 7 \\
\hline 1 & Menyajikan Masalah & 4 & 4 & 8 & $80 \%$ & B \\
\hline 2 & Membuat Hipotesis & 3 & 4 & 7 & $70 \%$ & $\mathrm{C}$ \\
\hline 3 & Merancang percobaan & 4 & 4 & 8 & $80 \%$ & B \\
\hline 4 & $\begin{array}{l}\text { Melakukan Percobaan } \\
\text { untuk memperoleh } \\
\text { Informasi }\end{array}$ & 3 & 4 & 7 & $70 \%$ & $\mathrm{C}$ \\
\hline 5 & $\begin{array}{l}\text { Mengumpulkan data dan } \\
\text { menganalisis data }\end{array}$ & 4 & 4 & 8 & $80 \%$ & $\mathrm{~B}$ \\
\hline 6 & Membuat Kesimpulan & 4 & 3 & 7 & $70 \%$ & $\mathrm{C}$ \\
\hline & Jumlah & 22 & 23 & 45 & $74,99 \%$ & $\mathbf{C}$ \\
\hline
\end{tabular}

Berdasarkan tabel 4 di atas, terlihat bahwa aktivitas yang dilakukan siwa pada fase Menyajikan Masalah diperoleh skor 4 oleh pengamat 1 dan skor 4 oleh pengamat II. Skor rata-rata adalah 8. Persentase yang diperoleh pada fase Menyajikan Masalah adalah 80\% dan termasuk dalam kriteria baik.Sedangkan pada fase Merancang Percobaan diperoleh skor 3 oleh pengamat 1 dan skor 4 oleh pengamat II.Skor rata-rata adalah 7.Persentase yang diperoleh pada fase Merancang Percobaan adalah 70\% dan termasuk dalam kriteria cukup.Fase Melakukan Percobaan untuk memperoleh informasi, diperoleh skor 4 oleh pengamat 1 dan skor 4 oleh pengamat II. Skor rata-rata adalah 8 .

Persentase yang diperoleh pada fase melakukan untuk memperoleh informasi adalah $80 \%$ dan termasuk dalam kriteria baik.Mengumpulkan data 4, diperoleh skor 3 oleh pengamat 1 dan skor 4 oleh pengamat II.Skor rata-rata adalah 7.Persentase yang diperoleh pada fase mengumpulkan data adalah $70 \%$ dan termasuk dalam kriteria cukup.Fase menguji 
hipotesis diperoleh skor 4 oleh pengamat 1 dan skor 4 oleh pengamat II.Skor rata-rata adalah 8.Persentase yang diperoleh pada fase menguji hipotesis adalah $80 \%$ dan termasuk dalam kriteria baik.Fase membuat kesimpulan diperoleh membuat kesimpulan diperoleh skor 4 oleh pengamat 1 dan skor 3 oleh pengamat II.Skor rata-rata adalah 7. Persentase yang diperoleh pada fase membuat kesimpulan adalah $70 \%$ dan termasuk dalam kriteria baik. Keseluruhan skor rata-rata dari aktivitas guru adalah 45 dan persentase 74,99\%. Dengan demikian, termasuk dalam kriteria cukup.

\section{3) Analisis Tes Hasil Belajar Siklus I}

Analisis hasil tes belajar siswa siklus I dengan menggunakan model pembelajaran Inkuiri dengan jumlah soal 15 dan 4 pilihan jawaban.Tes siklus I diikuti oleh 20 orang siswa. Hasil belajar secara ringkas dapat dilihat pada tabel 5 berikut ini :

Tabel 5 Analisis Tes Hasil Belajar Siklus I

\begin{tabular}{|c|c|c|c|}
\hline No & Hasil Belajar & Jumlah & Persentase \\
\hline 1 & 2 & 3 & 4 \\
\hline 1. Tuntas & & 8 & $40 \%$ \\
\hline 2. Tidak Tuntas & & 12 & $60 \%$ \\
\hline Jumlah & & 20 & $100 \%$ \\
\hline
\end{tabular}

Berdasarkan tabel 5 diatas, terlihat bahwa siswa yang tuntas dalam belajar sebanyak 8 orang siswa dengan persentase $40 \%$, sedangkan siswa yang belum tuntas dalam belajar sebanyak 12 orang siswa dengan persentase 60\%. Dengan demikian secara klasikal ketuntasan dalam belajar masih belum tuntas dan perlu diberikan remedial.

\section{4) Refleksi Siklus I Tindakan II}

Berdasarkan hasil pengamatan dan analisis data yang diperoleh guru dari 2 orang pengamat selama siklus pertama, maka sudah terlihat adanya pengaruh dari penerapan pembelajaran dengan model pembelajaran Inkuiri. Pengaruh dari pertemuan yang diberikan oleh guru dapat dilihat dari keberhasilan dan kelemahan baik dari guru maupun dari siswa, antara lain:

a) Keberhasilan guru dan siswa

Adapun keberhasikan guru dan siswa dalam pembelajaran siklus pertama sebagai berikut :

- Suasana proses belajar mengajar berlangsung lebih lancar dan tertib

- Kegiatan menyampaikan tujuan pembelajaran dapat dilakukan dengan baik

- Kegiatan membentuk kelompok diskusi dapat dilakuakan dengan baik

- Kegiatan memberikan bimbingan kepada siswa ketika mengalami kesulitan dapat dilakukan dengan baik

- Aktivitas siswa dalam kegiatan belajar sudah meningkat, sehingga dapat dikatakan siswa lebih aktif 
- Keberanian siswa untuk menanyakan hal-hal yang sulit sudah mengalami peningkatan

b) Kelemahan guru dan siswa

Adapun kelemahan guru dan siswa selama pembelajaran siklus pertama sebagai berikut :

- Materi yang diajarkan masih sulit dipahami siswa

- Masih banyak siswa yang malas mengerjakan kerja kelompok, hal ini dikarenakan banyak siswa yang masih kurang mengerti tentang materi tumbuhan hijau

- Proses refleksi masih kurang lancar, karena hanya guru saja yang menjelaskan sedangkan siswa hanya mencatat apa yang dijelaskan

- Pertanyaan yang diberikan oleh guru belum dapat memotivasi siswa dengan baik, sehingga siswa kurang merespon pertanyaan tersebut

- Masih banyak siswa yang tidak berani bertanya hal yang sulit dipahami, sehingga guru harus menjelaskan hal yang sama untuk siswa yang berbeda.

\section{Siklus II Tindakan I}

\section{a. Perencanaan}

Tahap ini peneliti melakukan beberapa persiapan, diantarannya adalah menyiapkan Rencana Pelaksanaan Pembelajaran (RPP) dengan materi ketergantungan manusia dan hewan pada tumbuhan hijau, menyiapkan LKS yang berkaitan dengan materi yang akan dipelajari, menyiapkan alat dan bahan belajar seperti jenis-jenis tumbuhan hijau, menyiapkan lembar observasi aktivitas guru dan siswa untuk mengamati aktivitas guru dan siswa selama pelaksanaan pembelajaran.

\section{b. Pelaksanaan}

Tindakan I dilaksanakan sesuai dengan langkah-langkah yang tertera pada rencana pelaksanaan pembelajaran (RPP) sesuai dengan model pembelajaran Inkuiri. Tindakan I siklus II diikuti oleh 20 orang siswa.

Fase I : Orientasi

Guru memotivasi siswa dengan memberikan pertanyaan mengapa pentingnya tumbuhan hijau bagi manusia dan hewan sebagai sumber energi? Menginformasikan pentingnya materi tumbuhan hijau dan model pembelajaran yang akan digunakan yaitu model Inkuiri. Guru menjelaskan pokok-pokok kegiatan yang harus dilakukan oleh siswa untuk mencapai tujuan belajar. Guru memberikan permasalahan untuk membuktikan tentang tumbuhan hijau bagi manusia dan hewan sebagai sember energi.

Fase II : Membuat Hipotersis

Pada fase ini guru memberikan penjelasan, guru meminta siswa mencari jawaban sementara dari teks yang ada pada LKS 03 yang diberikan guru sesuai materi. Selanjutnya 
guru meminta siswa mengisi jawaban pada LKS 03. Guru membimbing siswa yang mengalami kesulitan dalam mengisi LKS.

Fase III : Merancang Percobaan

Guru mendemontrasikan langkah percobaan tentang manfaat tumbuhan hijau bagi manusia dan hewan, dan guru membimbing siswa dalam merancang percobaan di depan kelas. Selanjutnya guru membimbing siswa melakukan pengamatan pada percobaan yang telah didemontrasikan.

Fase IV : Melakukan Percobaan untuk memperoleh informasi

Guru membimbing siswa dalam kelompok belajar selanjutnya guru membentuk kelompok terdiri dari 4-5 orang siswa dan guru membimbing siswa untuk melakukan penyelidikan sesuai dengan demontrasikan yang telah diberikan.

Fase V : Mengumpulkan data dan menganalisis data

Pada fase ini membimbing siswa dalam kelompok untuk mencatat dan mendiskusikan hasil pengamatan. Serta guru memberikan bimbingan kepada siswa untuk menganalisis hasil pengamatan.Selanjutnya guru meminta siswa untuk membuat laporan hasil pengamatan, guru menyuruh siswa untuk mempresentasikan laporan hasil pengamatan kelompok didepan kelas dan kelompok lain menanggapinya.

Fase VI : Membuat Kesimpulan

Pada fase ini guru bersama dengan siswa membuat kesimpulan, guru menuliskan kesimpulan dari hasil pembelajaran, setelah siswa menulis kesimpulan di buku catatan.Kemudian guru memberikan latihan untuk dikerjakan dirumah, selanjutnya guru memberikan pesan moral kepada siswa.

\section{c. Pengamatan}

Pengamatan dilakukan bersamaan dengan pelaksanaan kegiatan pembelajaran.Dalam pelaksanaan pembelajaran peneliti dibantu oleh dua orang pengamat yang bertindak sebagai observator. Adapun indikator-indikator yang diamati meliputi aktivitas guru (peneliti) dalam pelaksanaan tindakan dan aktivitas siswa dalam proses belajar mengajar.

\section{d. Analisis dan Refleksi}

\section{1) Analisis Aktivitas Guru Siklus II Tindakan I}

Aktivitas guru dalam melaksanakan pembelajaran diamati dengan menggunakan lembar observasi kegiatan guru dalam pengelolaan model pembelajaran Inkuiri. Adapun hasil pengamatan aktivitas guru pada siklus II tindakan I terdapat pada tabel 6 berikut ini : 
Tabel 6 Analisis Aktivitas Guru Siklus II Tindakan I

\begin{tabular}{|c|c|c|c|c|c|c|}
\hline \multirow[t]{2}{*}{ No } & \multirow[t]{2}{*}{ Fase } & \multicolumn{2}{|c|}{$\begin{array}{c}\text { Skor } \\
\text { Aktivitas } \\
\text { Guru }\end{array}$} & \multirow[t]{2}{*}{$\begin{array}{l}\text { Skor } \\
\text { Rata- } \\
\text { Rata }\end{array}$} & \multirow[t]{2}{*}{ Persentase } & \multirow[t]{2}{*}{ Kriteria } \\
\hline & & PI & PII & & & \\
\hline 1 & 2 & 3 & 4 & 5 & 6 & 7 \\
\hline 1 & Menyajikan Masalah & 5 & 5 & 10 & $100 \%$ & SB \\
\hline 2 & Membuat Hipotesis & 4 & 4 & 8 & $80 \%$ & $\mathrm{~B}$ \\
\hline 3 & Merancang percobaan & 4 & 5 & 9 & $90 \%$ & SB \\
\hline 4 & $\begin{array}{l}\text { Melakukan Percobaan untuk } \\
\text { memperoleh Informasi }\end{array}$ & 5 & 5 & 10 & $100 \%$ & SB \\
\hline 1 & 2 & 3 & 4 & 5 & 6 & 7 \\
\hline 5 & $\begin{array}{l}\text { Mengumpulkan data dan } \\
\text { menganalisis data }\end{array}$ & 4 & 4 & 8 & $80 \%$ & B \\
\hline 6 & Membuat Kesimpulan & 5 & 5 & 10 & $100 \%$ & $\mathrm{~B}$ \\
\hline & Jumlah & 27 & 28 & 55 & $91,66 \%$ & SB \\
\hline
\end{tabular}

Berdasarkan tabel 6 diatas, terlihat bahwa aktivitas yang dilakukan guru pada fase Menyajikan Masalah diperoleh skor 5 oleh pengamat 1 dan skor 5 oleh pengamat II. Skor rata-rata adalah 10. Persentase yang diperoleh pada fase Menyajikan Masalah adalah $100 \%$ dan termasuk dalam kriteria sangat baik. Sedangkan pada fase membuat hipotesis diperoleh skor 4 oleh pengamat 1 dan skor 4 oleh pengamat II. Skor rata-rata adalah 8. Persentase yang diperoleh pada fase membuat hipotesis adalah $80 \%$ dan termasuk dalam kriteria baik.Fase merancang percobaan, diperoleh skor 4 oleh pengamat 1 dan skor 5 oleh pengamat II.

Skor rata-rata adalah 9. Persentase yang diperoleh pada fase merancang percobaan adalah $90 \%$ dan termasuk dalam criteria sangat baik.Mengumpulkan data 5, diperoleh skor 5 oleh pengamat 1 dan skor 4 oleh pengamat II. Skor rata-rata adalah 10. Persentase yang diperoleh pada fase mengumpulkan data adalah 100\% dan termasuk dalam kriteria sangat baik. Menguji hipotesis diperoleh skor 4 oleh pengamat 1 dan skor 4 oleh pengamat II. Skor rata-rata adalah 8.Persentase yang diperoleh pada fase menguji hipotesis adalah $80 \%$ dan termasuk dalam criteria baik. Fase membuat kesimpulan diperoleh skor 5 oleh pengamat 1 dan skor 5 oleh pengamat II. Skor ratarata adalah10. Persentase yang diperoleh pada fase membuat kesimpulan adalah $100 \%$ dan ternasuk dalam kriteria sangat baik. Keseluruhan skor rata-rata dari aktivitas guru adalah 55 peresentase $91,66 \%$. Dengan demikian, termasuk dalamk kriteria sangat baik.

\section{2) Analisis Aktivitas Siswa siklus II tindakan I}


Aktivitas siswa dalam melaksanakan pembelajaran dismsti dengan menggunakan lembar observasi kegiatan siswa dalam mengikuti model pembelajaran Inkuiri. Adapun hasil pengamatan aktivitas siswa pada siklus II tindakan I pada tabel 7 dibawah ini :

Tabel 7 Analisis Aktivitas Siswa Siklus II Tindakan I

\begin{tabular}{|c|c|c|c|c|c|c|}
\hline \multirow[t]{2}{*}{ No } & \multirow[t]{2}{*}{ Fase } & \multicolumn{2}{|c|}{$\begin{array}{c}\text { Skor } \\
\text { Aktivitas } \\
\text { Siswa }\end{array}$} & \multirow[t]{2}{*}{$\begin{array}{l}\text { Skor } \\
\text { Rata- } \\
\text { Rata }\end{array}$} & \multirow[t]{2}{*}{ Persentase } & \multirow[t]{2}{*}{ Kriteria } \\
\hline & & PI & PII & & & \\
\hline 1 & 2 & 3 & 4 & 5 & 6 & 7 \\
\hline 1 & Menyajikan Masalah & 5 & 5 & 10 & $100 \%$ & SB \\
\hline 2 & Membuat Hipotesis & 5 & 5 & 10 & $100 \%$ & SB \\
\hline 3 & Merancang percobaan & 4 & 4 & 8 & $80 \%$ & $\mathrm{~B}$ \\
\hline 4 & $\begin{array}{l}\text { Melakukan Percobaan } \\
\text { untuk memperoleh } \\
\text { Informasi }\end{array}$ & 4 & 5 & 9 & $90 \%$ & SB \\
\hline 5 & $\begin{array}{l}\text { Mengumpulkan data dan } \\
\text { menganalisis data }\end{array}$ & 5 & 4 & 9 & $90 \%$ & SB \\
\hline 6 & Membuat Kesimpulan & 5 & 5 & 10 & $100 \%$ & SB \\
\hline & Jumlah & 28 & 28 & 56 & 93,33\% & SB \\
\hline
\end{tabular}

Berdasarkan tabel 7 diatas, terlihat bahwa aktivitas yang dilakukan siswa pada fase Menyajikan Masalah diperoleh skor 5 oleh pengamat 1 dan skor 5 oleh pengamat II. Skor rata-rata adalah 10. Persentase yang diperoleh pada fase Menyajikan Masalah adalah $100 \%$ dan termasuk dalam kriteria sangat baik. Sedangkan pada fase Membuat Hipotesis diperoleh skor 5 oleh pengamat 1 dan skor 5 oleh pengamat II. Skor ratarata adalah 10. Persentase yang diperoleh pada fase Membuat Hipotesis adalah 100\% dan termasuk dalam kriteria sangat baik. Fase Merancang Percobaan, diperoleh skor 4 oleh pengamat 1 dan skor 4 oleh pengamat II.

Skor rata-rata adalah 8.Persentase yang diperoleh pada fase Merancang percobaan adalah $80 \%$ dan termasuk dalam kriteria baik. Melakukan percobaan untuk memperoleh informasi 4 , diperoleh skor 4 oleh pengamat 1 dan skor 5 oleh pengamat II. Skor rata-rata adalah 9. Persentase yang diperoleh pada fase melakukan percobaan untuk memperoleh informasi adalah $90 \%$ dan termasuk dalam kriteria sangat baik. Fase mengumpulkan data dan menganalisis data diperoleh skor 5 oleh pengamat 1 dan skor 4 oleh pengamat II. Skor rata-rata adalah 9. Persentase yang diperoleh pada fase Mengumpulkan data dan menganalisi data adalah 90\% dan termasuk dalam kriteria sangat baik. Fase membuat kesimpulan diperoleh skor 5 oleh pengamat 1 dan skor 5 oleh pengamat II. Skor rata-rata adalah 10. Persentase yang diperoleh pada fase membuat kesimpulan adalah $100 \%$ dan termasuk dalam kriteria sangat baik. 
Keseluruhan skor rata-rata dari aktivitas siswa adalah 56 dan persentase 93,33\%. Dengan demikian, termasuk dalam kriteria sangat baik.

\section{Refleksi Siklus II Tindakan I}

Berdasarkan hasil pengamatan dan analisis data yang diperoleh peneliti dan dua orang pengamat selama proses pembelajaran tindakan I siklus II, maka sudah terlihat pengaruh dari penggunaan model Inkuiri selama kegiatan pembelajaran berlangsung. Pengaruh dari tindakan yang diberikan guru dapat terlihat dari keberhasilan dan kelemahan, baik dari segi guru dan siswa antara lain :

a. Kelebihan guru dan siswa

- Kemampuan guru dalam menerapkan model pembelajaran Inkuiri dalam kegiatan belajar mengajar sudah berlangsung baik dengan persentase $91,66 \%$. Setiap tahap pembelajaran yang dilaksanakan guru telah mencapai kriteria baik dan sangat baik.

- Siswa telah mampu mengajukan pertanyaan yang tepat sesuai dengan materi yang dipelajarinya.

- Siswa yang mewakili kelompok sudah mampu mengkomunikasikan pengetahuan yang diperolehnya kepada anggota kelompok lainnya.

b. Kelemahan guru dan siswa

- Masih ada kegiatan tertentu yang didominasi oleh guru, terutama saat pelaksanaan kegiatan berdiskusi dalam kelompok, karena biasanya siswa tidak berdiskusi tetapi langsung mengisi LKS.

- Siswa masih kurang mampu menjalankan kegiatan pembelajaran pada kegiatan memberikan penjelasan teman-teman lainnya.

\section{Siklus II Tindakan II}

\section{a. Perencanaan}

Tahap ini peneliti melakukan beberapa persiapan, diantaranya adalah menyiapkan Rencana Pelaksanaan Pembelajaran (RPP) dengan materi pentingnya tumbuhan hijau bagi kehidupan manusia, menyiapkan LKS yang berkaitan dengan materi yang akan dipelajari, menyiapkan alat dan bahan belajar seperti gambar-gambar kehidupan tanpa tumbuhan hijau, menyiapkan lembar observasi aktivitas guru dan siswa untuk mengamati aktivitas guru dan siswa selama pelaksanaan pembelajaran, menyiapkan tes hasil belajar siswa siklus II, serta menyiapkan angket respon siswa terhadap pelaksanaan pembelajaran.

\section{b. Pelaksanaan}

Tindakan II dilaksanakan sesuai dengan langkah-langkah yang tertera pada Rencana Pelaksanaan Pembelajaran (RPP) sesuai dengan model pembelajaran Inkuiri.Tindakan II siklus II diikuti oleh 20 orang siswa.

Fase I : Menyajikan Masalah 
Pada fase ini memotivasi siswa dengan memberikan pertanyaan mengapa pentingnya tumbuhan hijau bagi manusia dan hewan sebagai sumber energi?. Menginformasikan pentingnya materi tumbuhan hijau dan model pembelajaran yang akan digunakan yaitu model Inkuiri. Guru menjelaskan pokok-pokok kegiatan yang harus dilakukan oleh siswa untuk mencapai tujuan belajar. Guru memberikan permasalahan untuk membuktikan tentang tumbuhan hijau bagi manusia dan hewan sebagai sumber energi.

Fase II : Membuat Hipotesis

Pada fase ini guru meminta siswa mencari jawaban sementara dari teks yang ada pada LKS 04 yang diberikan guru sesuai materi. Guru meminta siswa mengisi jawaban pada LKS 04 dan guru membimbing siswa yang mengalami kesulitan dalam mengisi LKS.

Fase III : Merancang Percobaan

Guru mendemontrasikan langkah percobaan tentang manfaat tumbuhan hijau bagi manusia dan hewan, guru membimbing siswa dalam merancang percobaan didepan kelas dan guru membimbing siswa melakukan pengamatan pada percobaan yang telah didemontrasikan.

Fase IV : Melakukan percobaan untuk memperoleh informasi

Guru membimbing siswa dalam kelompok belajar dan guru membentuk kelompok terdiri dari 4-5 orang siswa. Selanjutnya guru membimbing siwa untuk melakukan penyelidikan sesuai dengan demontrasi yang telah diberikan.

Fase V : Mengumpulkan data dan menganalisis data

Pada fase ini guru membimbing siswa dalam kelompok untuk mencatat dan mendiskusikan hasil pengamatan, guru memberikan bimbingan kepada siswa untuk menganalisis hasil pengamatan, guru meminta siswa untuk membuat laporan hasil pengamatan, guru menyuruh siswa untuk mempresentasikan laporan hasil pengamatan kelompok di depan kelas dan kelompok lain menangapinya.

Fase VI : Membuat Kesimpulan

Pada fase ini guru merefleksi hasil diskusi dan presentasi kelompok. Guru memberikan informasi lebih lanjut tentang tumbuhan hijau sebagai sumber makanan bagi tumbuhan dan hewan. Guru meminta siswa untuk membuat rangkuman pembelajaran.

\section{c. Pengamatan}

Pengamatan dilakukan bersamaan dengan pelaksanaan kegiatan pembelajaran.Dalam pelaksanaan pembelajaran peneliti dibantu oleh dua orang pengamat yang bertindak sebagai observator. Adapun indikator-indikator yang diamati meliputi aktivitas guru (peneliti) dalam pelaksanaan tindakan dan aktivitas siswa dalam proses belajar mengajar.

\section{d. Analisis dan Refleksi}

\section{1) Analisis Aktivitas Guru siklus II Tindakan II}


Aktivitas guru dalam melaksanakan pembelajaran diamati dengan menggunakan lembar observasi kegiatan guru dalam pengelolaan model pembelajaran Inkuiri. Adapun hasil pengamatan aktivitas guru pada siklus II tindakan II terdapat pada tabel 8 berikut ini.

\section{Tabel 4.8 Analisis Aktivitas Guru Siklus II Tindakan II}

\begin{tabular}{|c|c|c|c|c|c|c|}
\hline \multirow[t]{2}{*}{ No } & \multirow[t]{2}{*}{ Fase } & \multicolumn{2}{|c|}{$\begin{array}{c}\text { Skor } \\
\text { Aktivitas } \\
\text { Guru }\end{array}$} & \multirow[t]{2}{*}{$\begin{array}{l}\text { Skor } \\
\text { Rata- } \\
\text { Rata }\end{array}$} & \multirow[t]{2}{*}{ Persentase } & \multirow[t]{2}{*}{ Kriteria } \\
\hline & & PI & PII & & & \\
\hline 1 & 2 & 3 & 4 & 5 & 6 & 7 \\
\hline 1 & Menyajikan Masalah & 5 & 5 & 10 & $100 \%$ & SB \\
\hline 2 & Membuat Hipotesis & 5 & 5 & 10 & $100 \%$ & SB \\
\hline 3 & Merancang percobaan & 4 & 4 & 8 & $80 \%$ & $\mathrm{~B}$ \\
\hline 4 & $\begin{array}{l}\text { Melakukan Percobaan } \\
\text { untuk memperoleh } \\
\text { Informasi }\end{array}$ & 4 & 5 & 9 & $90 \%$ & SB \\
\hline 5 & $\begin{array}{l}\text { Mengumpulkan data } \\
\text { dan menganalisis data }\end{array}$ & 5 & 4 & 9 & $90 \%$ & SB \\
\hline 6 & Membuat Kesimpulan & 5 & 5 & 10 & $100 \%$ & SB \\
\hline & Jumlah & 28 & 28 & 56 & $93,33 \%$ & SB \\
\hline
\end{tabular}

Berdasarkan tabel 8 di atas, terlihat bahwa aktivitas yang dilakukan guru pada fase menyajikan masalah diperoleh skor 5 oleh pengamat 1 dan skor 5 oleh pengamat II.Skor rata-rata adalah 10. Persentase yang diperoleh pada fase menyajikan masalah adalah $100 \%$ dan termasuk dalam kriteria sangat baik. Sedangkan pada fase membuat hipotesis diperoleh skor 5 oleh pengamat 1 dan skor 5 oleh pengamat II. Skor rata-rata 10.Persentase yang diperoleh pada fase membuat hipotesis adalah $100 \%$ dan termasuk dalam kriteria sangat baik. Fase merancang percobaan, diperoleh skor 4 oleh pengamat 1 dan skor 4 oleh pengamat II.

Skor rata-rata adalah 8. Persentase yang diperoleh pada fase merancang percobaan adalah $80 \%$ dan termasuk dalam kriteria baik. Melakukan untuk memperoleh informasi 4, diperoleh skor 4 oleh pengamat 1 dan skor 5 oleh pengamat II. Skor ratarata adalah 9. Persentase yang diperoleh pada fase melakukan percobaan untuk memperoleh informasi adalah $90 \%$ dan termasuk dalam kriteria sangat baik, diperoleh skor 5 oleh pengamat 1 dan skor 4 diperoleh oleh pengamat II. Skor rata-rata adalah 9. Persentase yang diperoleh pada fase melakukan percoaan untuk memperoleh informasi adalah 90\% dan termasuk dalam kriteria sangat baik. Fase membuat kesimpulan diperoleh skor 5 oleh pengamat 1 dan skor 5 oleh pengamat II. Skor ratarata adalah 10. Persentase yang diperoleh pada fase membuat kesimpulan adalah $100 \%$ dan termasuk dalam kriteria sangat baik. Keseluruhan skor rata-rata dari 
aktivitas guru adalah 56 dan persentase 93,33\%. Dengan demikian, termasuk dalam kriteria sangat baik.

\section{2) Analisis Aktivitas Siswa Siklus II Tindakan II}

Aktivitas siswa dalam melaksanakan pembelajaran diamati dengan menggunakan lembar observasi kegiatan siswa dalam mengikuti model pembelajaran Inkuiri. Adapun hasil pengamatan aktivitas siswa pada siklus I tindakan I terdapat pada tabel 9 di bawah ini:

\section{Tabel 4.9 Analisis Aktivitas Siswa Siklus II Tindakan II}

\begin{tabular}{|c|c|c|c|c|c|c|}
\hline \multirow[t]{2}{*}{ No } & \multirow[t]{2}{*}{ Fase } & \multicolumn{2}{|c|}{$\begin{array}{c}\text { Skor } \\
\text { Aktivitas } \\
\text { Siswa } \\
\end{array}$} & \multirow[t]{2}{*}{$\begin{array}{l}\text { Skor } \\
\text { Rata- } \\
\text { Rata }\end{array}$} & \multirow[t]{2}{*}{ Persentase } & \multirow[t]{2}{*}{ Kriteria } \\
\hline & & PI & PII & & & \\
\hline 1 & 2 & 3 & 4 & 5 & 6 & 7 \\
\hline 1 & Menyajikan Masalah & 5 & 5 & 10 & $100 \%$ & SB \\
\hline 2 & Membuat Hipotesis & 4 & 5 & 9 & $90 \%$ & SB \\
\hline 3 & Merancang percobaan & 5 & 4 & 9 & $90 \%$ & SB \\
\hline 1 & 2 & 3 & 4 & 5 & 6 & 7 \\
\hline 4 & $\begin{array}{l}\text { Melakukan Percobaan } \\
\text { untuk memperoleh } \\
\text { Informasi }\end{array}$ & 5 & 5 & 10 & $100 \%$ & SB \\
\hline 5 & $\begin{array}{l}\text { Mengumpulkan data } \\
\text { dan menganalisis data }\end{array}$ & 5 & 4 & 9 & $90 \%$ & SB \\
\hline 6 & Membuat Kesimpulan & 5 & 5 & 10 & $100 \%$ & SB \\
\hline & Jumlah & 29 & 28 & 57 & $94,99 \%$ & SB \\
\hline
\end{tabular}

Berdasarkan tabel 9 diatas, terlihat bahwa aktivitas yang dilakukan siswa pada fase menyajikan masalah diperoleh skor 5 oleh pengamat 1 dan skor 5 oleh pengamat II.Skor rata-rata adalah 10. Persentase yang diperoleh pada fase menyajikan masalah adalah $100 \%$ dan termasuk dalam kriteria sangat baik. Sedangkan pada fase membuat hipotesis diperoleh skor 4 oleh pengamat 1 dan skor 5 oleh pengamat II. Skor rata-rata adalah 9. Persentase yang diperoleh pada fase membuat hipotesis adalah $90 \%$ dan termasuk dalam kriteria sangat baik. Fase merancang percobaan diperoleh skor 5 oleh pengamat 1 dan skor 4 oleh pengamat II.

Skor rata-rata adalah 9. Persentase yang diperoleh pada fase merancang percobaan adalah $90 \%$ dan termasuk dalam kriteria baik. Melakukan percobaan untuk memperoleh informasi diperoleh skor 5 oleh pengamat 1 dan skor 5 oleh pengamat II.Skor rata-rata adalah 10. Persentase yang diperoleh pada fase melakukan percobaan untuk memperoleh informasi adalah $100 \%$ dan termasuk dalam kriteria sangat baik. Fase mengumpulkan data dan menganalisis data diperoleh skor 5 oleh pengamat 1 dan skor 4 oleh pengamat II. Skor rata-rata adalah 9. Persentase yang diperoleh pada fase 
mengumpulkan data dan menganalisis data adalah $90 \%$ dan termasuk dalam kriteria sangat baik. Fase membuat kesimpulan diperoleh skor 5 oleh pengamat 1 dan skor dan skor 5 oleh pengamat II. Skor rata-rata adalah 10. Persentase yang diperoleh pada fase membuat kesimpulan adalah $100 \%$ dan termasuk dalam kriteria sangat baik. Keseluruhan skor rata-rata dari aktivitas guru adalah 57 dan persentase 94,99\%. Dengan demikian, termasuk dalam kriteria sangat baik.

\section{3) Analisis Tes Hasil Belajar siklus II}

Analisis hasil tes belajar siswa siklus II dangan menggunakan model pembelajaran Inkuiri dengan jumlah soal 15 dan 4 pilihan jawaban.Tes siklus II diikuti oleh 20 orang siswa. Hasil belajar secara ringkas dapat dilihat pada tabel 10 berikut ini:

Tabel 4.10 Analisis Tes Hasil Belajar Siklus II

\begin{tabular}{cccc}
\hline No & Hasil Belajar & Jumlah & Persentase \\
\hline $\mathbf{1}$ & $\mathbf{2}$ & $\mathbf{3}$ & $\mathbf{4}$ \\
\hline 1 & Tuntas & 16 & $80 \%$ \\
2 & Tidak Tuntas & 4 & $20 \%$ \\
\hline & Jumlah & $\mathbf{2 0}$ & $\mathbf{1 0 0 \%}$ \\
\hline
\end{tabular}

Berdasarkan tabel 10 diatas, terlihat bahwa siswa yang tuntas dalam belajar sebanyak 16 orang siswa dengan persentase $80 \%$ sedangkan siswa yang belum tuntas dalam belajar sebanyak 4 orang siswa dengan persentase 20\%. Dengan demikian secara klasikal sudah mengalami ketuntasan dalam belajar.

\section{4) Analisis Respon Siswa}

Pengambilan data respon siswa terhadap model pembelajaran Inkuiri menggunakan angket respon siswa, hasil yang diperoleh disajikan dalam tabel 11 sebagai berikut :

Tabel 11 Analisis Angket Respon Siswa

\begin{tabular}{|c|c|c|}
\hline No & Respon Siswa & Persentase \\
\hline 1 & 2 & 3 \\
\hline i. Senang & & $85,5 \%$ \\
\hline ii. Tidak Senang & & $4,5 \%$ \\
\hline
\end{tabular}

Berdasarkan tabel 11 diatas, terlihat bahwa siswa yang menyatakan setuju dengan persentase $85,5 \%$. Sedangkan yang menyatakan tidak setuju dengan persentase $4,5 \%$. Rata-rata persentase pada perangkat pembelajaran dengan menggunakan model pembelajaran Inkuiri dengan persentase $85,5 \%$.

\section{Pembahasan}

Seperti yang telah dijelaskan pada bab-bab sebelumnya. Penelitian ini bertujuan untuk meningkatkan hasil belajar siswa pada materi tumbuhan hijau dengan menggunakan model pembelajaran Inkuiri. Berdasarkan hasil uraian dari hasil penelitian yang diperoleh dari siklus I dan siklus II, maka dapat diketahui bahwa penggunaan model pembelajaran Inkuiri ternyata 
dapat meningkatkan hasil belajar siswa, ini dapat ditinjau dari segi proses dan dari segi hasil yang telah ditetapkan pada tiap siklus. Pada siklus I hasil belajar siswa yang dicapai siswa belum memenuhi kriteria yang telah ditetapkan, baik dari proses maupun dari segi hasil. Oleh karena itu, peneliti melanjutkan ke siklus II hasil belajar yang dicapai siswa sudah memenuhi kriteria yang ditetapkan baik dari segi proses maupun dari segi hasil.

Hasil tes akhir siklus I yang diperoleh siswa belum mencapai kriteria yang ditetapkan yaitu hanya $40 \%$ atau 8 orang siswa yang mendapat skor $\geq 73$. Karena pada ujian akhir siklus I banyak siswa yang belum bisa menjawab soal-soal yang diberikan dan persentasenya belum memcapai kriteria yang ditetapkan.Adapun faktor yang menyebabkan siswa tidak tuntas dalam pembelajaran pada siklus I karena siswa pada saat guru menyampaikan materi siswa kurang mengerti dan kurang memperhatikan materi tersebut, oleh sebab itu hasil belajar siswa tidak tuntas.Kemudian meningkat dan memenuhi kriteria pada siklus II yaitu sebesar $80 \%$ atau 16 orang siswa sudah mendapat skor $\geq 73$. Hal ini tidak terlepas dari peran guru yang sukses dalam menyampaikan materi dan siswa yang sudah memperhatikan disaat guru menyampaikan materi dan hasilnya siswa mampu memahami dan mengerti pembelajaran yang disampaikan oleh guru. Dari hasil tersebut dapat disimpulkan bahwa hasil belajar siswa mengalami peningkatan dari siklus I ke siklus II.

Hasil observasi yang diperoleh dari aktivitas guru pada siklus I tindakan I dan tindakan II hampir memenuhi kriteria yang ditetapkan yaitu mencapai skor persentase rata-rata $73,33 \%$ dan $75 \%$, pada siklus I tindakan I dan II, guru dalam memberikan motivasi kurang, sehingga perhatian siswa masih kurang fokus terhadap pembelajaran. Kemudian meningkat lagi pada siklus II tindakan I dan tindakan II mencapai kriteria yaitu sebesar 91,66\% dan 93,33\%, dikarnakan pada siklus ke II ini tindakan I dan tindakan II, guru sudah mampu menerapkan model pembelajaran Inkuiri dalam kegiatan belajar mengajar sudah berlangsung baik sehingga aktivitas guru pada siklus II tindakan I dan tindakan II telah mencapai kriteria baik dan sangat baik.Dari hasil tersebut dapat disimpulkan bahwa aktivitas guru meningkat dari siklus I ke siklus II. Sedangkan hasil observasi terhadap aktivitas siswa pada siklus I tindakan I dan tindakan II belum memenuhi kriteria yang ditetapkan yaitu hanya mencapai skor $73,33 \%$ dan $74,99 \%$ termasuk dalam kategori cukup dikarnakan diamana perhatian siswa masih rendah ketika guru menyampaikan materi pelajaran dan pada tahap pembentukan kelompok siswa masih terlihat kurang menerima keberadaan kelompok, ketika siswa mengerjakan LKS juga terlihat lebih menonjol siswa yang pintar sedangkan siswa yang lainnya memperhatikan saja. Kemudian meningkat dan mencapai kriteria pada siklus II tindakan I dan tindakan II yaitu sebesar 93,33\% dan 94,99\% termasuk dalam kategori sangat baik dikarnakan pada siklus II tindakan I dan tindakan II, dimana siswa telah mampu mengajukan pertanyaan yang tepat sesuai denagan materi yang dipelajari dan siswa sudah mampu mengkomunikasikan pengetahuan yang diperolehnya pada materi tumbuhan hijau dengan model pembelajaran Inkuiri. Dari hasil tersebut dapat disimpulkan bahwa aktivitas siswa meningkat dari siklus I dan siklus II. 
Berdasarkan hasil respon siswa terhadap model pembelajaran Inkuiri pada materi tumbuhan hijau menunjukkan bahwa sekitar $85,5 \%$ siswa setuju belajar IPA dengan menggunakan model Inkuiri pada materi tumbuhan hijau, mereka benar-benar senang mempelajari materi dengan model pembelajaran Inkuiri sehingga mereka lebih aktif dan hasil belajar siswa dapat ditingkatkan. Dari uraian diatas tersebut dapat disimpulkan bahwa respon siswa terhadap pembelajaran Inkuiri mengalami perubahan. Sesuai dengan kriteria keberhasilan yang digunakan dalam penelitian ini yaitu "jika observasi telah mencapai skor $\geq 80 \%$. Sedangkan kriteria hasil adalah jika $\geq 80 \%$ siswa mendapat $\geq 73$ pada tes akhir siklus. Maka suatu pembelajaran dikatakan berhasil.

Dengan demikian, dari hasil yang diperoleh dapat diketahui bahwa proses belajar mengajar yang mengacu pada pembelajaran Inkuiri dapat meningkatkan hasil belajar siswa baik dari segi proses maupun dari segi hasil. Hal ini dapat terlihat dari hasil yang diperoleh pada siklus I yang mengalami peningkatan pada siklus II. Pembelajaran dengan menggunakan model Inkuiri dapat memotivasi siswa untuk belajar dimana setiap kegiatan dari model pembelajaran Inkuiri dapat memberi kesempatan kepada siswa untuk melatih pengetahuan dan keterampilan mereka.

Dengan demikian dapat disimpulkan bahwa penggunaan pembelajaran Inkuiri pada materi tumbuhan hijau dapat meningkatkan hasil siswa kelas V SD negeri 8 Peusangan. Hal ini menunjukkan bahwa pelaksanaan penelitian dikelas V SD Negeri 8 peusangan sudah berhasil dengan penggunaan pembelajaran model pembelajaran Inkuiri pada materi tumbuhan hijau.

\section{SIMPULAN}

Berdasarkan hasil penelitian dan pembahasan yang telah peneliti paparkan pada bab-bab terdahulu, maka pada bab ini peneliti akan memaparkan beberapa kesimpulan yang berkaitan dengan hasil pelaksanaan penelitian yang telah dilakukan pada siswa kelas V SD Neegeri 8 peusangan pada materi tumbuhan hijau. Adapun kesimpulan yang dapat diambil pada penelitian ini adalah sebagai berikut:

1. Terjadi peningkatan Hasil belajar siswa pada siklus I yang tuntas sebesar $40 \%$, siklus II yang tuntas sebesar $80 \%$, sehingga peningkatan hasil belajar siswa dari siklus I ke siklus II Meningkat sebesar $40 \%$.

2. Aktivitas guru dan siswa, pembelajaran IPA pada materi tumbuhan hijau dengan menggunakan model pembelajaran Inkuiri dari tiap siklus mengalami peningkatan. Aktivitas guru pada siklus I adalah 75\%. Dan pada siklus II persentase menjadi 93,33\%. Sedangkan aktivitas siswa juga meningkat dari siklus I dengan persentase $73,33 \%$ dan pada siklus II Menjadi 94,99\%.

3. Respon siswa kelas V SD Negeri 8 peusangan terhadap penerapan model pembelajaran Inkuiri pada materi tumbuhan hijau mendapatkan respon dengan kriteria yang baik, yaitu $85,5 \%$ siswa menjawab setuju, dan hanya $4,5 \%$ yang menjawab tidak setuju dengan komponen kegiatan pembelajaran yang peneliti terapkan dalam mempelajari menggunakan model pembelajaran Inkuiri. 


\section{DAFTAR PUSTAKA}

1. Arikunto, S. 2010. PenelitianTindakan Kelas. Jakarta: Bumi Aksara.

2. Dimyati, Mudjiono. 2009. Belajar dan Pembelajaran. Jakarta: Rineka Cipta.

3. Elisa, N., Muthmainnah dan Saputra, S. 2018. Upaya Meningkatkan Hasil Belajar Siswa dengan Model Pembelajaran Kooperatif Tipe Snowball Throwing Pada Materi Daur Hidup Hewan. https://osf.io/y9cr3/. Tanggal Akses 20 April 2018. DOI 10.17605/OSF.IO/TC7GW

4. Moleong, L.J. 2010.Metodologi Penelitian Kualitatif. Bandung: Remaja Rosda karya.

5. Mudjiono, 2009.Belajar dan Pembelajaran. Jakarta: Rineka Cipta.

6. Mulyasa, 2009.Praktik Penelitian Tindakan Kelas. Bandung: Rosda Karya.

7. Saputra, S. 2016. Pengaruh Model Pembelajaran Discovery Learning Berbasis Lingkungan Sekolah terhadap Hasil Belajar Siswa Pada Materi Keanekaragaman Hayati. JESBIO. Vol V No 2.

8. Sudjana, 2010. Penilaian Hasil Proses Belajar Mengajar (Cet.XV). Bandung: PT. Remaja Rosda Karya.

9. Suprijono Agus, 2011. Cooperative Learning Teori dan Aplikasi Paikem. Yogyakarta: Pustaka Pelajar.

10. Trianto, 2009. Mendesain Model Pembelajaran Inovatif Progresif : Konsep, Landasan, dan Implementasinya pada Kurikulum Tingkat Satuan Pendidikan (KTSP). Jakarta: Kencana Prenada Media Group. 